\title{
NATURALIZACJA A POAKCESYJNE MIGRACJE: MOTYWY UBIEGANIA SIĘ O STATUS OBYWATELA PAŃSTWA PRZYJMUJĄCEGO NA PRZYKŁADZIE POLAKÓW W ISLANDII
}

\section{Monika Nowicka*}

\begin{abstract}
Abstrakt
Celem artykułu jest rekonstrukcja powodów, dla których polscy imigracji w Islandii chcą się ubiegać o przyznanie islandzkiego obywatelstwa. W wyniku przeprowadzonej analizy zostały wyróżnione cztery główne motywacja przemawiające za przyjęciem obywatelstwa islandzkiego: 1) możliwość bezwizowego podróżowania do USA; 2) ubieganie się o obywatelstwo „na wszelki wypadek"; 3) uzyskanie praw, które mają tylko autochtoni oraz 4) możliwość decydowania o losach społeczności, w której się mieszka. Analiza jest oparta na pół-ustrukturyzowanych wywiadach pogłębionych zrealizowanych w Islandii w roku 2014.
\end{abstract}

Słowa kluczowe: obywatelstwo, migracje, Islandia, naturalizacja, integracja

\section{NATURALIZATION AND POST-ACCESSION MIGRATIONS: MOTIVES FOR APPLYING FOR THE STATUS OF A CITIZEN OF THE RECEIVING STATE ON THE EXAMPLE OF POLES IN ICELAND}

Abstract

The purpose of the article is to reconstruct the reasons why Polish immigrants in Iceland want to apply for Icelandic citizenship. As a result of the analysis, four main motivations for adopting Icelandic citizenship were distinguished: 1) the possibility of visa-free travel to the USA; 2) applying for citizenship "just in case"; 3 ) obtaining rights that only the Icelanders have and 4) the ability to decide about the fate of the community in which immigrants live. The analysis is based on semi-structured in-depth interviews carried out in Iceland in 2014 .

Keywords: citizenship, migration, Iceland, naturalization, integration

*Dr Monika Nowicka, Collegium Civitas, e-mail: monika.nowicka@civitas.edu.pl 
Wstęp

Od 2007 roku Polacy są największą grupą imigrancką w Islandii. Napływ Polaków wiązał się przede wszystkim z otwarciem islandzkiego rynku pracy w 2006 roku, w latach 2009-2011 nastąpiło zmniejszenie liczby polskich pracowników na wyspie będące konsekwencją kryzysu, który rozpoczął się w Islandii w roku 2008. Od roku 2012 liczba Polaków na wyspie systematycznie rośnie, w 2017 było ich 13 811, co stanowiło 4\% całej populacji oraz 30\% imigrantów (Statistics Iceland 2017).

Polska imigracja do Islandii jest częścią polskiej emigracji poakcesyjnej, która jest określana jako „migracja płynna” charakteryzująca się brakiem przewidywalności oraz zdefiniowania zakresu czasowego, geograficznego i funkcjonalnego (Okólski 2009: 30). Imigranci płynni mogą elastycznie reagować na zmiany społeczno-polityczno-gospodarcze w państwie przyjmującym i w zależności od nich kształtować swoją karierę migracyjną. Migranci poakcesyjni przestali snuć dalekosiężne plany, a kolejna wędrówka jest brana przez wielu z nich pod uwagę, jeśli zajdzie taka koniczność, tym samym emigracja przestała wiązać się $\mathrm{z}$ osiedleniem się $\mathrm{w}$ państwie przyjmującym, a stała się otwartym projektem.

Nowy model migracji jest konsekwencją ustanowienia swobodnego przepływu pracowników wewnątrz państw Unii Europejskiej. Art. 45 Traktatu o Funkcjonowaniu Unii Europejskiej (2009) nie tylko dopuszcza swobodne przemieszczanie się w poszukiwaniu pracy, ale także znosi wszelką dyskryminację pracowników państw członkowskich ze względu na przynależność państwową w zakresie zatrudnienia, wynagradzania i innych warunków pracy. Oznacza to, że migranci unijni korzystający z prawa do swobodnego przepływu powinni mieć, te same prawa pracownicze, co autochtoni. Zgodnie z Rozporządzeniem Parlamentu Europejskiego i Rady (UE) nr 492/2011 z dnia 5 kwietnia 2011 r. w sprawie swobodnego przepływu pracowników wewnątrz Unii (2011), 
mobilni pracownicy korzystają z takich samych przywilejów podatkowych i socjalnych jak pracownicy krajowi ${ }^{1}$. Ustanowienie powyżej opisanych praw sprawiło, że imigranci wewnątrz Unijni stracili motywację do aplikowania o obywatelstwo państw przyjmujących.

Celem artykułu jest rekonstrukcja powodów, dla których polscy imigracji w Islandii chcą się naturalizować. Analiza jest oparta na 39 półustrukturyzowanych wywiadach pogłębionych zrealizowanych w Islandii w 2014 roku. Zrealizowano 17 indywidualnych rozmów z tzw. „Zwykłymi imigrantami”, czyli osobami, które nie angażowały się w życie społeczne polskiej mniejszości w Islandii, 17 „liderskich” z działaczami organizacji polonijnych w Islandii. Osoby te były traktowane jako informatorzy, ale niejednokrotnie odwoływały one się do swoich osobistych doświadczeń migracyjnych.

W trakcie badania zostały zrealizowane 3 wywiady grupowe: dwa z nich były przeprowadzone z osobami, które pełniły formalne funkcje w dwóch polskich stowarzyszeniach działających w Reykjaviku: Projekt: Polska.is oraz Stowarzyszenie Przyjaciół Szkoły Polskiej w Reykjaviku. W trzecim przypadku rozmówcami były dwie osoby zaangażowane w działalność Towarzystwa Przyjaźni Polsko-Islandzkiej. Wywiady były zbierane w Reykjaviku, na północy Islandii w Akureyrii oraz na wschodzie kraju w Reyðarfjörður.

Asymilacja i integracja jako strategie adaptacyjne imigrantów

Problem adaptacji imigrantów do społeczeństwa przyjmującego jest jednym z kluczowych zagadnień w socjologii, a coraz częściej jest również tematem ożywionej debaty politycznej i społecznej (por. Murray 2017;

\footnotetext{
' Rozporządzenie ma znaczenie dla państw Europejskiego Obszaru Gospodarczego, a więc także i dla Islandii. Egzekwowanie praw zawartych w Traktacie o funkcjonowaniu Unii Europejskiej (2009) oraz w Rozporządzeniu 492/2011 podkreśla Dyrektywa Parlamentu Europejskiego i Rady 2014/54/UE (2014) w sprawie środków ułatwiających korzystanie z praw przyznawanych pracownikom w kontekście swobodnego przepływu pracowników, która ustanawia przepisy ułatwiające jednolite stosowanie i egzekwowanie praw wynikających ze swobodnego przepływu pracowników.
} 
Scheffer 2010). W naukach społecznych można wyróżnić cztery główne strategie adaptacyjne: asymilację, integrację, separację i marginalizację. Historycznie najdłużej opisywana przez socjologów jest asymilacja, która jest także ściśle związana z amerykańską tradycją socjologiczną (Glazer 1993, Trevena 2008).

Badacze nie uzgodnili wspólnego rozumienia asymilacji (podobnie jak pozostałych terminów). Najczęściej paradoksalnie stawiają ją w opozycji do integracji. Jedna z pierwszych definicji asymilacji określają jako proces jednostronny, który ma doprowadzić do takiego włączenia grupy mniejszościowej w grupę większościową, aby mniejszość stała się nierozpoznawalna (Kellor 1913, za Glazer 1993).

Rozumienie asymilacji zaczęło się zmieniać na mniej totalizujące przemianę imigrantów. Zaczęto zauważać różne wymiary asymilacji (Gordon 1964: 60-83), przestano ją postrzegać jako uniwersalny sposób inkorporacji imigrantów (Morawska 1994), zauważono, że imigranci nie muszą asymilować się do jednego wzorca, którym była kultura białej klasy średniej, dopuszczano możliwość asymilacji do różnych grup (Portes, Zhou 1993) oraz że asymilacja dotyczy także grupy przyjmującej, ona również musi się zmienić w celu zniwelowania różnic wynikających z pochodzenia etnicznego (Alba, Nee 2003).

Integracja jest pojęciem młodszym od asymilacji, jest związana $\mathrm{z}$ europejską tradycją opisu włączania imigrantów w społeczeństwo przyjmujące i jest pojęciem znacznie bardziej problematycznym i wieloznacznym niż asymilacja. Integracja, w odróżnieniu od asymilacji, nie wymaga od imigranta odejścia od swojej kultury i tradycji, określa ona stan w którym imigranci „przy zachowaniu swojej odrębności kulturowej, wchodzą w relatywnie trwałe związki ze społeczeństwem przyjmującym i uczestniczą w różnych obszarach jego życia (...) oraz poszanowanie przez imigrantów podstawowych norm, wartości i instytucji społeczeństwa przyjmującego" (Grzymała-Kazłowska 2008: 35-36). 
Tak rozumiana integracja jest procesem jednostronnym, a zmieniającą się grupą jest grupa mniejszościowa. Integracja może być także definiowana jako proces dwustronny wymagający przystosowania się nie tylko imigrantów do społeczeństwa przyjmującego, ale także grupy goszczącej i jej instytucji do nowoprzybyłych członków społeczeństwa (Castles et al. 2002). Na integrację można także spojrzeć z perspektywy samych imigrantów: imigrant jest zintegrowany, gdy czuje, że przynależy do społeczności przyjmującej, a „poczucie przynależności jest odbiciem integracji z sieciami społecznymi i instytucjami” (Wu, Schimmele Hou 2012: 383). Integracja może być także rozumiana jako strategia, w której imigrant chce utrzymać swoją kulturę i jednocześnie szuka kontaktów z inną kulturą (Berry 1997).

Rozszerzając definicję Berry'ego odnoszącą się jedynie do aspektu kulturowego integracji, przyjmuję, że integracja to strategia, w której imigrant funkcjonuje zarówno w społeczeństwie przyjmującym, jak i w społeczeństwie/społeczności wysyłającej. W odniesieniu do obywatelstwa będzie to oznaczać, że przyjęcie obywatelstwa państwa przyjmującego i jednoczesne pozostawienie obywatelstwa państwa wysyłającego jest przejawem integracji jako podjętej strategii adaptacyjnej².

\section{Czynniki wpływające na integrację imigrantów}

Co powoduje, że imigrant decyduje się na realizację integracyjnej strategii adaptacyjnej? Badacze zajmujący się procesami integracji wyróżniają różne grupy czynników wpływających na podjęcie decyzji o realizowaniu strategii integracyjnej.

\footnotetext{
${ }^{22}$ Korzystając z modelu Berry'ego można wyodrębnić także trzy pozostałe strategie adaptacyjne odnoszące się do obywatelstwa: 1) asymilację, kiedy imigrant przyjmuje obywatelstwa państwa przyjmującego, rezygnując z obywatelstwa państwa wysyłającego, 2) separację, gdy imigrant nie ubiega się o obywatelstwo państwa przyjmującego jednak zachowuje obywatelstwo państwa wysyłającego, 3) marginalizację imigrant nie ubiega się o obywatelstwo kraju przyjmującego i traci obywatelstwo państwa wysyłającego.
} 
Alastair Ager i Alison Strang (2004) wyróżniają cztery grupy czynników mających wpływ na integrację: 1) sprawcy i zasoby, do których należą zatrudnienie, zamieszkanie, edukacja i zdrowie; 2) znajomości, czyli kapitał społeczny, którym dysponuje imigrant; 3) ułatwienia do których autorzy zaliczają znajomość języka i kultury oraz bezpieczeństwo i stabilność; 4) fundamenty, czyli obywatelstwo i prawa. Zdaniem autorów przedstawione grupy czynników nie muszą być odczytywane ani hierarchicznie, ani sekwencyjnie. Prawa obywatelskie mogą być definiowane zarówno jako podstawa i czynnik niezbędny do dalszej integracji, jako zwieńczenie procesu integracji lub równolegle $\mathrm{z}$ innymi czynnikami jako czynnik wspomagający.

Inni badacze najczęściej wskazują na następujące grupy czynników: związane ze społeczeństwem przyjmującym i jego instytucjami, związane ze społecznością etniczną imigranta oraz związane z samym migrantem.

Richard Alba i Victor Nee (2003: kl 551) rozróżniają mechanizmy bliskie, które działają na poziomie jednostek, grup pierwotnych i wspólnot (na poziomie sieci) oraz dalekie, które mają swoje źródła w instytucjach społeczeństwa przyjmującego. Mechanizmy bliskie są kształtowane m.in. przez formy kapitałów, które posiadają jednostki. Jednostki są definiowane jako podmioty podejmujące celowe działania dążące do polepszenia ich sytuacji. Wybory imigrantów są dokonywane na bazie niepełnych informacji z uwzględnieniem przekonań kulturowych mających wpływ na określenie dobrze pojętego własnego interesu. Mechanizmy dalekie to „strukturalne motywatory osadzone w środowisku instytucjonalnym” (Ibidem: $\mathrm{kl}$ 722). Imigranci mają różny dostęp do różnych grup struktur możliwości (np. do rynku pracy, czy opieki medycznej)

Hartmut Esser (2010) stworzył Model Integracji Międzygeneracyjnej, majacy pozwolić na odtworzenie mechanizmów wyjaśniających rezultaty adaptacji imigrantów do społeczeństwa przyjmującego. Model ten składa się z trzech części: podstawowych opcji, które mają do 
dyspozycji imigranci; funkcji, które tworzą związek pomiędzy podstawowymi opcjami, a warunkami empirycznymi oraz z wyników strukturalnych, które są zagregowanym rezultatem indywidualnych wyborów.

Na podstawowe opcje składają się 1) kontekst społeczeństwa przyjmującego; 2) kontekst etniczny. Podjęcie działań w każdym z tych dwóch kontekstów wiąże się z pewną suma negatywnych lub pozytywnych zwrotów z podjętego działania (Esser nazywa tę sumę wagq UE). Jednostki podejmują te działania, które przynoszą najwyższe zwroty. Imigrant kalkulujący, czy dane działanie jest opłacalne, bierze pod uwagę zasoby własne (kapitały: kulturowy, ekonomiczny i społeczny) oraz ich wartość w kontekście a) społeczeństwa przyjmującego; b) etnicznym. Aby móc zrealizować cele wyznaczone przez społeczeństwo przyjmujące, imigranci muszą zainwestować w kapitał, który ma najwyższą wartość dla społeczeństwa przyjmującego, np. nauka języka, często jest to bardzo kosztowna inwestycja, a imigrant nie ma gwarancji, że poniesione koszty się zwrócą i awansuje w strukturze socjoekonomicznej. W takiej sytuacji imigrant może zdecydować się na działanie w kontekście etnicznym, separując się od społeczeństwa przyjmującego.

W modelu ważne są także dwie podstawowe funkcje: 1) wielkość grupy imigracyjnej oraz 2) tworzenie granic etnicznych. Wielkość grupy etnicznej zależy od a) absorpcji imigrantów przez społeczeństwo przyjmujące; b) napływu nowych imigrantów. Tworzenie granic etnicznych jest budowane na dwóch podstawach: a) strukturalnej (granice powstają w wyniku segregacji przestrzennej lub strukturalnej); b) mentalnej (są wynikiem uprzedzeń). Tworzenie granic etnicznych przyczynia się do spadku wysokości zwrotu z działania w kontekście społeczeństwa przyjmującego, a powoduje wzrost zwrotu z działań podjętych w kontekście etnicznym.

Aby wyjaśnić motywy naturalizacji imigrantów proponuję model lączący obydwie propozycje teoretyczne. Zgodnie z przedstawioną powyżej definicją integracji imigranci nie muszą wybierać po między kontekstem spoleczeństwa przyjmującego i etnicznym, jeśli uznają to za 
opłacalne mogą funkcjonować w obydwu równocześnie, pod warunkiem, że uznają to za najbardziej opłacalne rozwiązanie. Opłacalność rozwiązanie jest wynikiem kalkulacji, na który wpływ mają zasoby, które posiada imigrant (mechanizmy bliskie) i jego habitus oraz uwarunkowania strukturalne (mechanizmy dalekie). Proponuję, aby mechanizmy dalekie rozszerzyć o strukturalne tworzenie granic wspólnoty obywatelskiej, a nie tylko ograniczać je do kultury, ekonomii oraz przestrzeni.

Obywatelstwo w ujęciu socjologicznym

Obywatelstwo odnosi się do członkostwa we wspólnocie politycznej, w (po)nowoczesnym świecie jest statusem, który wiąże jednostkę z państwem narodowym. Dla większości ludzi obywatelstwo jest statusem przypisanym, dlatego też rzadko w życiu codziennym bywa ono przedmiotem refleksji: obywatel/ka nie zastanawia się, w jaki sposób nabył/a swoje prawa, co dzięki nim zyskuje, ani jak jego lub jej życie wyglądałoby bez tych praw.

Postrzeganie obywatelstwa zmienia się w przypadku decyzji o emigracji do nowego państwa, a posiadanie obywatelstwa może stać się jedną z kluczowych kwestii dnia codziennego: „dostęp do obywatelstwa staje się problemem tylko dla międzynarodowych migrantów, którzy opuścili państwo dające im naturalnie przyrodzony status obywatela na rzecz państwa, w którym obywatelami nie są” (Joppke 2010: 34).

Migrant, w większości przypadków, może zabrać ze sobą w podróż rodzinę, pieniądze, na miejscu może mówić w swoim ojczystym języku i praktykować swoje zwyczaje kulturowe, obywatelstwo oraz wynikające z niego prawa (i obowiązki) pozostają w państwie wysyłającym. W dobie globalnych migracji przyznawanie statusu obywatela staje się także problemem dla państw, które imigrantów przyjmują, dlatego też warunki naturalizacji są dokładnie określone przez akty prawne i ulegają 
zmianie w zależności od sytuacji społeczno-gospodarczo-politycznej w danym kraju. Status obywatelski przestaje być naturalnie przypisaną cechą jednostki, a staje się narzędziem wkluczająco-wykluczającym, przy pomocy którego jednostki niepożądane we wspólnocie są pozostawiane poza jej obrębem. W zależności od polityki integracyjnej danego państwa naturalizacja imigranta może być finalnym produktem procesu integracyjnego lub jego warunkiem wstępnym (Ager, Strang 2004).

W podobnym duchu o integracji obywatelskiej piszą Castles i Davidson (2000: 84), którzy wyróżniają dwa aspekty obywatelskiej integracji imigrantów: stawanie się obywatelem (dostęp do obywatelstwa), którego uwieńczeniem jest „otrzymanie paszportu państwa przyjmującego” (obywatelstwo jako zwieńczenie procesu integracji) oraz „obywatelstwo substancjalne, które oznacza równe szanse uczestnictwa w różnych obszarach życia społecznego, takich jak polityka, rynek pracy, system zabezpieczeń społecznych i kultura” (obywatelstwo jako warunek wstępny integracji). Zatem obywatelstwo to z jednej strony status z drugiej powiązana z tym statusem rola społeczna (Raciborski 2010, Bukowska, Wnuk-Lipiński 2005).

Obywatelstwo jak wiele innych terminów w naukach społecznych jest pojęciem wieloznacznym. Ulrich Preuß (1993: 85) wyróżnia trzy znaczenia terminu obywatelstwo: 1) może ono być pojęciem prawnym oznaczającym przynależność państwową; 2) ,jako aktywny współudział i uczestnictwo w politycznych problemach społeczeństwa”; oraz 3) jako udział w społeczeństwie obywatelskim, czyli w tym obszarze, którego „struktury i formy porozumienia są tworzone i określane nie przez nadrzędną instytucję państwową, lecz wynikają z niepaństwowych politycznych form uwspólnotowienia”.

Blomeraad et al. (2008: 155-158) wyróżniają cztery wymiary obywatelstwa: 1) obywatelstwo jako status prawny analizowane przez pryzmat dostępności statusu obywatela dla określonych grup; 2) obywatelstwo jako prawa, tu obywatelstwo jest rozumiane jako kontrakt pomiędzy 
państwem a jednostką określający wzajemne prawa i obowiązki; 3) obywatelstwo jako partycypacja polityczna w rządzeniu na określonym terytorium; 4) obywatelstwo jako przynależność, która pociąga za sobą reguły inkluzji i ekskluzji - aby wytworzyło się „my”, muszą też być „oni”.

Zatem obywatelstwo można postrzegać w wymiarach: państwowyniepaństwowy oraz statusowy-partycypacyjny, a także w wymiarze swój-obcy. Obywatelstwo może być rozpatrywane także w aspekcie formalnym związanym ze statusem prawnym jednostek oraz z obywatelstwem aktywnym. Na potrzeby prowadzonej analizy obywatelstwo jest rozumiane jako kontrakt pomiędzy państwem a jednostką określające prawa i obowiązki.

Naturalizacja Polaków w Islandii - mechanizmy dalekie

Jeszcze do niedawna obywatelstwo było ściśle związane z państwem narodowym, którego granice jednocześnie wyznaczały obszar, na którym prawa obywatelskie były w mocy. Wraz z ustanowieniem obywatelstwa Unii Europejskiej w Traktacie z Maastrich (1992), prawa obywatelskie, a przynajmniej ich część, przekroczyły granice państw narodowych33. Granice wspólnoty obywatelskiej zostały wyznaczone na ponadnarodowym poziomie.

W ten sposób obywatelstwo zostało osłabione jako narzędzie wkluczająco-wykluczające, gdyż prawa wynikające ze statusu obywatela przysługują wszystkim obywatelom UE pracującym w granicach Unii. Migranci znaleźli się w całkiem nowej sytuacji - naturalizacja nie jest konieczna, aby mogli korzystać z praw społecznych, cywilnych i części praw politycznych. Sytuacja ta stała się udziałem poakcesyjnych emigrantów z Polski.

3 Obywatelstwo UE przysługuje tylko obywatelom państw członkowskich, nie można być obywatelem UE nie będą jednocześnie obywatelem państwa członkowskiego. Samo przyznanie obywatelstwa pozostaje $w$ dalszym ciągu w domenie państwa, natomiast prawa wynikające z obywatelstwa mogą być przenoszone. 
Islandzkie regulacje dotyczące naturalizacji cudzoziemców zmieniały się kilkukrotnie od roku 1918. Obecnie zgodnie z art 8 Icelandic Nationality Act (1952), aplikant powinien być rezydentem w Islandii przez 7 lat, lub przez 4 lata jeśli jest obywatelem innego państwa Nordyckiego4. Pozostałe wymagania odnoszą się do sytuacji finansowej aplikanta oraz niekaralności. Specyfiką islandzkiej procedury jest wymóg przedstawienia pisemnych zaświadczeń o dobrej reputacji aplikanta od dwóch obywateli islandzkich. Aplikant musi także złożyć egzamin z języka islandzkiego. Decyzja o przyznaniu obywatelstwa jest podejmowana przez Parlament. Obecnie aplikanci nie są zobowiązani do zrzeczenia się pierwszego obywatelstwa5.

Dane OECD/UE (2015) za rok 2015 rok pokazują, że poziom naturalizacji w państwach UE i EOG wśród obywateli urodzonych w Europie jest niższy niż w przypadku obywateli państw trzecich. Otwarcie granic i rozszerzenie praw cywilnych i socjalnych na wszystkie państwa EOG sprawiło, że naturalizacja w przypadku migrantów wewnętrznych nie jest ani konieczna ani atrakcyjna. OECD podaje, że mniej niż połowa migrantów będących obywatelami UE i EOG decyduje się na naturalizację w społeczeństwie przyjmującym.

Zupełnie inaczej jest w przypadku Europejczyków, którzy wyemigrowali do USA, Kanady czy Australii, w tym przypadku wskaźnik naturalizacji wynosi ponad 80\% (Ibidem). Prawidłowość ta ma potwierdzenie w przypadku imigrantów w Islandii. Znacznie wyższy odsetek obywateli państw trzecich ubiega się o Islandzkie obywatelstwo niż Polaków. W roku 2016 jedynie 13\% Polaków przebywających w Islandii posiadało islandzkie obywatelstwo, Filipińczyków 70\% (Statistics Iceland 2016).

\footnotetext{
4 Istnieją odstępstwa od tej reguły dla współmałżonków obywatela Islandii.

5 Islandia zniosła zakaz podwójnego obywatelstwa dopiero w XXI wieku, poprawką 9/2003 do Ustawy z roku 1952 (Johannesson et al. 2013: 17).
} 
Powody ubiegania się o status obywatela - mechanizmy bliskie

W czasie prowadzenia badań wielu z polskich imigrantów przebywających w Islandii mogło już ubiegać się o naturalizację po 7-letnim okresie rezydencji. Opisana powyżej uprzywilejowana pozycja polskim imigrantów w stosunku do imigrantów z państw trzecich powoduje, że ubieganie się o naturalizację nie jest koniecznością, a wolnym wyborem. Skutkiem takiego stanu rzeczy jest różnorodność motywów towarzyszących decyzji o aplikowaniu o obywatelstwo islandzkie.

Brak konieczności ubiegania się o obywatelstwo powoduje zróżnicowanie postaw wobec obywatelstwa jako takiego. Generalnie można wyróżnić dwa rodzaje postaw wobec obywatelstwa akceptację i odrzucenie w dwóch wymiarach: racjonalnym i symbolicznym. Postawy te są przejawiane zarówno do obywatelstwa polskiego jak i obywatelstwa islandzkiego. Polscy imigranci w Islandii zdecydowanie kierują się racjonalnością w uzasadnieniach (ewentualnej) aplikacji o obywatelstwo islandzkie.

Wymiar racjonalny w wiąże się z ważeniem argumentów za i przeciw przyjęciem obywatelstwa w różnych obszarach życia: imigranci ważą korzyści jakie mogą mieć z islandzkiego obywatelstwa. Decyzja o naturalizacji nie jest aktem przystąpienia do wspólnoty politycznej, a racjonalną kalkulacją odnoszącą się do maksymalizacji zysków i minimalizacji kosztów. Z punktu widzenia polskich imigrantów ubieganie się o naturalizację jest niejednoznaczne w perspektywie korzyści i strat. Korzyści i straty wynikające z podjęcia lub nie decyzji o naturalizacji mają wymiar materialny i niematerialny.

Przeprowadzona analiza pozwoliła wyodrębnić następujące narracje dotyczące decyzji o rozpoczęciu procesu naturalizacji: obywatelstwo jako przepustka, obywatelstwo jako czynnik wyrównujący szanse, obywatelstwo jako instrument pozwalający wpływać na losy wspólnoty, obywatelstwo jako polisa ubezpieczeniowa. 
Obywatelstwo jako przepustka - integracja konsumencka

Pierwszy aspekt, do którego odnosili się badani Polacy, to podróżowanie i posiadanie paszportu islandzkiego oraz korzyści, które się z tym wiążą. Obywatele Islandii nie muszą ubiegać się o wizę do wielu państw na całym świecie, w tym do Stanów Zjednoczonych Ameryki Północnej, co było bardzo częstym argumentem podawanym przez badanych za przyjęciem obywatelstwa islandzkiego. Jednocześnie niejednokrotnie był to jedyny argument, który przekonywał polskich imigrantów: „No, to da więcej możliwości, ponieważ na paszporcie islandzkim można wjechać do 153 krajów, także nie potrzebuje się wizy do Ameryki, Kanady czy też tych krajów. Także no fajnie tak" $(22)^{6}$.

Postrzeganie przez badanych islandzkiego paszportu jako znacznie lepszego od polskiego jest wyolbrzymione. Po pierwsze obywatele polscy mogą bez wiz wjeżdżać do Kanady. Po drugie, ranking paszportów przeprowadzony w roku 2016 przez Henley \& Partners (2016: 2) pokazuje, że paszport islandzki nie jest tak mocny jak powszechnie uważają badani i jest nieznacznie mocniejszy od paszportu polskiego. Paszport islandzki został sklasyfikowany na 10 miejscu razem z paszportem węgierskim i czeskim dając bezwizowy dostęp do 167 państw. Polski paszport znalazł się na 15 miejscu umożliwiając bezwizowy wjazd do 161 państw. Paszporty były klasyfikowane do 104 pozycji.

Atrakcyjność paszportu islandzkiego ma znaczenie symboliczne: umożliwia on bezwizowy wjazd do Stanów Zjednoczonych Ameryki Północnej, które od XIX wieku były tradycyjnym kierunkiem emigracji Polaków, do roku 2004 były drugim krajem emigracyjnym Polaków, ustępując pierwszeństwa tylko Republice Federalnej Niemiec (Główny Urząd Statystyczny 2015).

\footnotetext{
${ }^{6}$ Ten i następne cytaty oznaczone sygnaturą numeryczną pochodzą z wypowiedzi respondentów, uzyskanych podczas badań opisanych w początkowej części artykułu.
} 
Narracja badanych ujawniała obywatela konsumenta, dla którego obywatelstwo jest dobrem-przepustką służącą zaspokojeniu pragnienia przekroczenia granicy mitycznego kraju, jakim wciąż dla wielu są Stany Zjednoczone.

Możliwość podróżowania bezwizowego łączy się też z mobilnością stratyfikacyjną w ponowoczesnym świecie: „Dzisiaj zniesienie wiz wyjazdowych ma głębokie znacznie symboliczne (...) dostęp do poruszania się po świecie stał się współcześnie najwyższej wagi czynnikiem klasyfikacji społecznej. Niektórzy z nas cieszą się nową swobodą poruszania się sans papiers, podczas gdy inni z tych samych powodów nie mogą trwać bez ruchu" (Bauman 2000: 104).

Uzyskanie paszportu, który daje większe możliwości swobodnego poruszania się między państwami jest ponowoczesnym awansem klasowym, do pierwszego świata, świata turystów, dla których granice nie mają znaczenia, gdyż z „mocnym paszportem” mogą je z łatwością pokonywać (i są mile widziani w docelowych krajach swojej podróży), żyją jedynie w czasie, przestrzeń nie stanowi dla nich ograniczenia. Alter-ego turysty z mocnym paszportem jest włóczęga, który w odróżnieniu od turysty mającego wybór jest zmuszony przemieszczać się pokonując kolejne kontrole migracyjne, gdyż jego słaby paszport czyni z niego osobę w wielu miejscach niechcianą.

Ten typ motywacji można także interpretować używając kategorii Maxa Webera (2002: 17-19). Motywacja badanych do posiadania islandzkiego paszportu ma swoje źródło w ciągle aktualnym afekcie jakim Polacy darzą Stany Zjednoczone. Kochana na odległość Ameryka, o której realiach niewiele przeciętny Polak wie, jest w dalszym ciągu elementem polskiej mitologii narodowej (por. Napiórkowski 2018). Z tego względu ubieganie się o obywatelstwo islandzkie można traktować jako działanie afektywne, dające dostęp do wyobrażonej ziemi obiecanej.

Obywatelstwo często jest nazywane „paszportem” i jest to dominujący sposób mówienia o obywatelstwie. Mówienie o islandzkim obywatelstwie 
jako o „paszporcie” oddziela obywatelstwo od tożsamości narodowej (ubiegam się o islandzki paszport, ale nie o islandzką tożsamość, w dalszym ciągu pozostaję Polką/Polakiem) i w pewien sposób oddziela też obywatelstwo od państwa. Posiadanie paszportu nie było postrzegane jako długotrwałe zobowiązanie, nie trzeba do procesu naturalizacji podchodzić z przekonaniem. Może to być naturalizacja do następnego razu, kiedy migrant przy wyjeździe do kolejnego państwa będzie się ubiegać o naturalizację. Jest to zdecydowanie dominujący sposób postrzegania obywatelstwa i główny typ integracji wśród badanych Polaków w Islandii.

Obywatelstwo jako polisa ubezpieczeniowa - integracja przez przezorność

Drugim motyw, którym kierowali się badani, to asekuracja oraz pewna przezorność. Jedna z badanych nie odczuwała potrzeby posiadania obywatelstwa islandzkiego (a także nie spełniała warunków formalnych ubiegania się o obywatelstwo), jednak w przyszłości brała pod uwagę możliwość naturalizowania się, traktując je jednocześnie jako coś co nie przeszkadza, a może się kiedyś przydać.

W opisywanym przypadku obywatelstwo było poniekąd traktowane jako bezpłatne zabezpieczenie: „No nie zaszkodzi, nie zaszkodzi. To nie jest tak, że ja się chcę stać Islandką, jak jestem Polką i zawsze będę Polką, ale jeżeli już podjęłam tę decyzję, żeby przeprowadzić się tutaj. To myślę, że mi to nie zaszkodzi” (15).

Takie podejście do kwestii obywatelstwa pokazuje, że badana myślała o nim jedynie w kategorii praw i zabezpieczeń, pomijając kwestie obowiązków, które z nim się wiążą. Traktowanie obywatelstwa islandzkiego jako polisy ubezpieczeniowej wpisuje się, w to co Ulrich Beck opisuje jako „wystąpienia na barykady przeciw ryzyku” (2002: 93). Badana nie artykułuje obaw o np. zwrot antyimigracyjny w Islandii, czy wyjście Polski z Unii Europejskiej jednak chce mieć dodatkowe zabezpieczenie przed ewentualnym, jeszcze nienazwanym ryzykiem, które szacuje nie 
na podstawie własnych doświadczeń, ale ogólnej wiedzy. Ryzyko przeciw któremu działa badana ma swoje źródło w uwarunkowaniach ponadjednostkowych związanych z makro i mega strukturami (mechanizmy dalekie).

Obywatelstwo jako wyrównanie szans - integracja racjonalna

Trzeci z argumentów przywoływanych przez badanych wiązał się z wyrównaniem szans pomiędzy Islandczykami a imigrantami. Osoby, które posługiwały się tym argumentem, były przekonane, że państwo islandzkie faworyzuje swoich obywateli w stosunku do osób nieposiadających obywatelstwa islandzkiego. Nierówności wymienione przez badanych dotyczyły różnych obszarów życia.

Jedna z poruszanych kwestii wiązała się z możliwością nabycia gruntów, do którego prawo posiadają tylko obywatele islandzcy: ,ja bez tego nie mogę kupić gruntu, bo jeżeli nie będę miał islandzkiego paszportu, nie będę pełnym Islandczykiem, bo cudzoziemcy nie mogą kupić gruntu. Muszę kupić, ponieważ... znaczy muszę, chcę kupić, ponieważ jest z tego interes" (31).

W przytoczonym przypadku brak prawa do zakupu gruntu kolidował z planami biznesowymi badanego - chciał on rozpocząć kolejną działalność gospodarczą - jego zdaniem dochodową, jednak brak obywatelstwa uniemożliwiał mu to. Zatem decyzja o ubieganiu się o obywatelstwo islandzkie nosi znamiona racjonalności.

Kolejny przypadek związany z wyrównaniem szans wiązał się z możliwością uzyskania świadczeń od państwa islandzkiego: badana chciała uzyskać kredyt studencki ,jeśli ma się islandzkie obywatelstwo to łatwiej dostaje się kredyt studencki, a już na pewno jeśli chodzi o studiowanie za granicą, a mam taki plan studiowania za granicą, (...), wówczas na pewno potrzebowałabym islandzkiego obywatelstwa, żeby dostać tak wysoki kredyt na studiowanie za granicą" (25). 
Wartym odnotowania jest fakt, że obydwa przytoczone przypadki związane z chęcią wyrównania szans poprzez uzyskanie obywatelstwa islandzkiego miały charakter inwestycyjny: były związane z poprawieniem swojej sytuacji ekonomicznej poprzez założenie nowego biznesu $\mathrm{w}$ pierwszym przypadku lub zainwestowanie w swoją edukację w drugim. Kolejna z badanych odniosła się do wyrównania szans w ogóle obywatelstwo zrównuje szanse imigrantów i Islandczyków, ponieważ daje możliwość głosowania w wyborach: „Płacąc podatki w tym kraju, ja chce być traktowana na równi, że ja tu jestem, ja tu istnieję, mam prawo głosu"(17). Zatem tutaj imigranci uznawali, że inwestycja w obywatelstwo islandzkie przyniesie wysoki zwrot (wysoka waga UE).

W przytaczanych narracjach obywatelstwo jest instrumentem zrównującym szanse i nadającym oraz chroniącym prawa jednostki. Tak postrzegane obywatelstwo jest bliskie koncepcji „rzadkiego obywatelstwa” (thin citizenship), o którym pisał Rainer Baubock: obywatelstwo sprowadza się do legalnego statusu: „obywatelstwo raczej wiąże jednostkę [imigranta - M.N.] z państwem, a nie z wspólnotą polityczną" (1999: 6-7). Prawa obywatelskie były postrzegane przez pryzmat wolności negatywnej pozostawiającej decyzje dotyczące wspólnoty i zaangażowanie w jej życie i sprawy poza zainteresowaniami obywatela.

Obywatelstwo jako narzędzie wpływu na losy wspólnoty - integracja przez zaangażowanie

Kolejną motywacją do podjęcia starań o uzyskanie obywatelstwa była możliwość decydowania o sytuacji społeczno-politycznej w Islandii: „Jakby coś, co mnie interesuje w obywatelstwie, to branie udziału w wyborach parlamentarnych tak naprawdę... to jest dla mnie najbardziej interesujące w obywatelstwie, a poza tym? Nie mam takiej potrzeby [ubiegać się o obywatelstwo - M.N]”(21). Przytoczony cytat pokazuje, że badani mogą utożsamiać obywatelstwo z zaangażowaniem politycznym i decydowaniem 
o losie wspólnoty, w której aktualnie przebywają, a nie tylko i wyłącznie jako element ułatwiający życie w Islandii (obywatelstwo gęste, thick citizenship - Baubock 1999).

Potrzeba możliwości wpływu na sytuację społeczno-polityczną może także się wiązać z posiadaniem dzieci w Islandii, szczególnie w przypadku imigrantek i imigrantów, których dziecko przyszło na świat na wyspie: ,ja chcę głosować, dla mnie jest to np. bardzo ważne, że w tym miejscu, w którym ja żyję i (...) moje dziecko, że ja mam prawo do głosu, że ja mam prawo wyboru.” (17).

Innym czynnikiem wzmacniającym chęć współdecydowania o wspólnocie były nie zawsze racjonalne działania Islandczyków, którzy w ostatnich wyborach parlamentarnych w roku 2013 przywrócili do władzy partię Niepodległości, która doprowadziła do kryzysu w 2008 roku: „człowiek czuje się taki bezsilny, że nic już nie może zmienić, wygrywa partia, (...), ale mój głos też by nic nie zaważył, ale mi się wydaje, że dojrzewam do tego i z praktycznych względów i może też takich, że właśnie więcej wiem, co tu się dzieje (...), że po prostu rzeczywiście mogę zagłosować, ale brałam udział w tych lokalnych [wyborach - M.N.]” (5).

Ta wypowiedź, mimo wyrażonego poczucia bezsilności i braku wiary w jednostkową moc sprawczą, była jednak optymistyczna, gdyż uważała głosowanie za akt świadomy, wymagający pewnej wiedzy, szczególnie na poziomie wyborów krajowych w czasie, których zapadają decyzje dotyczące całego społeczeństwa. Ważne (i dość nietypowe) jest to, że badani odnosili się argumentów racjonalnych - aby móc poprawić swoją sytuację w kraju przyjmującym, należy mieć wpływ na podejmowane tam decyzje polityczne dotyczące uwarunkowań strukturalnych, w których funkcjonują imigranci.

Oprócz kalkulacji związanych z przyjęciem obywatelstwa islandzkiego, pojawiła się także motywacja odnosząca się do kategorii pozaracjonalnych. Jedna z badanych przyznała, że chce mieć obywatelstwo islandzkie, ponieważ mieszka w Islandii i tam jest jej dom: „Dlatego, że 
nie planuję powrotu do Polski w ogóle. No nie wiem, co będzie jutro, co będzie za rok, ale na dzień dzisiejszy nie planuję absolutnie powrotu tam. Tu jest mój dom, tu chcę zostać i dlatego chcę mieć to obywatelstwo, dlatego, że się zdecydowałam żyć tutaj” (3). Z jednej strony badana podkreśla swoje plany na przyszłość i fakt, że Islandia jest jej domem, co jest nietypowe nie tylko dla Polaków w Islandii, ale dla poakcesyjnych płynnych migrantów w ogóle, z drugiej strony dopuszcza możliwość, że sytuacja się zmieni i będzie zmuszona opuścić wyspę, co jest typową strategią charakteryzująca płynną migrację.

\section{Podsumowanie}

Ustanowienie obywatelstwa Unii Europejskiej oraz wynikających z niego praw, w tym prawa do swobodnego przemieszczania się i praw związanych ze swobodnym przepływem pracowników spowodowało, że migracja stała się projektem otwartym, a ścieżki migracyjne są budowane w zależności o czynników społeczno-gospodarczo-politycznych oraz indywidualnych potrzeb migrantów. Obywatelstwo jako narzędzie wkluczająco-wykluczające oraz przyznające prawa, straciło znacznie na znaczeniu. $Z$ tego względu bardzo niewielu polskich imigrantów w Islandii decyduje się na przyjęcie obywatelstwa państwa przyjmującego.

W wyniku przeprowadzonej analizy zostały wyróżnione cztery główne motywacja przemawiające za przyjęciem obywatelstwa islandzkiego: 1) możliwość bezwizowego podróżowania do USA - obywatelstwo jako przepustka (integracja konsumencka); 2) ubieganie się o obywatelstwo „na wszelki wypadek" - obywatelstwo jako polisa ubezpieczeniowa (integracja przez przezorność); 3) uzyskanie praw, które mają tylko autochtoni - obywatelstwo jako wyrównanie szans (integracja racjonalna) oraz 4) możliwość decydowania o losach społeczności, w której się mieszka - obywatelstwo jako narzędzie wpływu na losy wspólnoty (integracja zaangażowana). Głównym typem narracji o obywatelstwie było 
traktowanie go jako przepustki (integracja konsumencka), pozostałe typy narracji były w zdecydowanej mniejszości.

Bibliografia

Ager A., Strang A. (2004), Indicators of Integration. Final Report, Home Office, London

Alba R., Nee V. (2003), Remaking the American Mainstream. Assimilation and Contemporary Immigration, Harvard University Press, Cambridge-Massachusetts- London

Baubock R. (1999), National Community, Citizenship and Cultural Diversity, Institute for Advanced Studies, Vienna Bauman Z. (2000), Globalizacja, PIW, Warszawa Beck U. (2002), Społeczeństwo ryzyka, Scholar, Warszawa Berry J.W. (1997), Immigration, Acculturation and Adaptation, “Applied Psychology: An International Review" Vol. 46, No. 1

Blomeraad I., Korteweg A., Yurdakul G. (2008), Citizenship and Immigration: Multiculturalism, Assmililation, and Challenges to the $\mathrm{Na}$ tion-State, "Annual Review of Sociology" Vol. 34

Bukowska X., Wnuk-Lipiński E. (2009), Obywatelskość a la polonaise - czyli jakimi obywatelami sa Polacy, „Nauka” nr 1

Castles S., Davidson A. (2000), Citizenship and Migration. Globalization and politics of belonging, Routledge, New York

Castles S., Korac M., Vasta E., Vertovec S. (2002), Integration: map ping the field, Report of a Project carried out by the University of Oxford Centre for Migration and policy Research and Refugee Studies Centre contracted by the Home Office Immigration Research and Statistics Service (IRSS)

Dyrektywa Parlamentu Europejskiego i Rady 2014/54/UE z dnia 16 kwietnia 2014 r. w sprawie środków ułatwiających korzystanie 
z praw przyznanych pracownikom w kontekście swobodnego przepływu pracowników (2014), Dz.U. UE L 128/8, https://eur-lex.europa.eu/eli/dir/2014/54/oj

Esser H. (2010), Assimilation, Ethnic Stratification, or Selective Acculturation?. Recent Theories of the Integration of Immigrants and the Model of Intergenerational Integration, „Sociologica”, Fascicolo 1, doi: 10.2383/32055

Glazer N. (1993), Is assimilation dead?, "The Annals of the American Academy of Political and Social Science" Vol. 530

Główny Urząd Statystyczny (2015), Główne kierunki emigracji i imigracji $w$ latach 1966-2014, http://stat.gov.pl/obszary-tematyczne/ludnosc/migracje-ludnosci/glowne-kierunki-emigracji-iimigracji-w-latach-1966-2014-migracje-na-pobyt-staly,4,1.html

Gordon M. (1964), Assimilation in American Life, Oxford University Press, New York

Grzymała-Kazłowska A. (2008), Integracja - próba rekonstrukcji pojęcia, w: Problemy integracji imigrantów. Koncepcje, badania, polityki, (red.) Grzymała-Kazłowska A., Łodziński S., Wydawnictwo Uniwersytetu Warszawskiego, Warszawa

Henley \& Patners (2016), Visa Restriction Index, https://www.henleyglobal.com/files/download/HP/hvri/HP\%2oVisa\%2oRestrictions \%20Index\%20160223.pdf

Icelandic Nationality Act (1952), No. 100/1952 (23 December), https://www.legislationline.org/documents/id/5320

Johannesson G.T., Petursson G.T., Bjornsson T. (2013), Country report: Iceland, EDUO Citizneship Observatory, Robert Schuman Centre for Advanced Studies, European University Institute, Florencehttp://eudo-citizenship.eu/admin/?p=file\&appl=countryProfiles\&f=Iceland.pdf

Joppke Ch. (2010), Citizenship and migration, Polity Press, Cambridge 
Morawska E. (1994), In Defense of Assimilation Model, "Journal of American Ethnic History" Vol. 13, No. 2

Murray D. (2017), Przedziwna śmierć Europy. Imigracja, tożsamość, islam, Zysk i S-ka, Poznań

Napiórkowski M. (2018), Stany Iluzji, „Tygodnik Powszechny” nr 16, https://www.tygodnikpowszechny.pl/stany-iluzji-152628

OECD/EU (2015), Civic engagement of immigrants, w: Indicators of Immigrant Integration 2015: Settling In, OECD Publishing, Paris, http://dx.doi.org/10.1787/9789264234024-14-en

Okólski M. (2009), Polskajako aktor na europejskiej scenie migracyjnej, w: Wspótczesne migracje: dylematy Europy i Polski, (red.) Duszczyk M., Lesińska M., Ośrodek Badań nad Migracjami, Uniwersytet Warszawski, Warszawa

Portes A., Zhou M. (1993), The New Second Generation: Segmented Generation and Its Variants, "The Annals of the American Academy of Political and Social Science" Vol. 530

Preuß U.K. (1993), O teoretyczno-konstytucyjnym pojęciu obywatelstwa we współczesnym społeczeństwie, w: Obywatel odrodzenia pojęcia, (red.) Markiewicz B., IFiS PAN, Warszawa

Raciborski J. (2010), Wprowadzenie: oblicza obywatelstwa, w: Praktyki obywatelskie Polaków, (red.) idem, IFiS PAN, Warszawa Rozporządzenie Parlamentu Europejskiego i Rady (UE) nr 492/2011 z dnia 5 kwietnia $2011 \mathrm{r}$. w sprawie swobodnego przepływu pracowników wewnątrz Unii (2011), Dz.U. UE L 141/1, https://eur-lex.europa.eu/legal-content/PL/TXT/?uri=celex\%3A32011Ro492

Scheffer P. (2010), Druga ojczyzna. Imigranci $w$ spoleczeństwie otwartym, Wydawnictwo Czarne, Wołowiec

Statistics Iceland (2016), Foreign citizens gaining Icelandic citizenship by country of birth, sex and age 1991-2016, http://px.hagstofa.is/pxen/pxweb/en/Ibuar/Ibuar_mannfjoldi_3_bakgrun- 
nur__Rikisfbr/MANo4120.px/table/ta-

bleViewLayout1/?rxid=148f64bb-3774-46ed-a739-4edcc34bob5a [09.05.2017]

Statistics Iceland (2017), Population by country of birth, sex and age 1 January 1998-2017, http://px.hagstofa.is/pxen/pxweb/en/Ibuar /Ibuar__mannfjoldi_3_bakgrunnur__Faedingarland/MAN12103. px/table/tableViewLayout1/?rxid=148f64bb-3774-46ed-a739-4edc c34bob5a [09.05.2017]

Traktat o Funkcjonowaniu Unii Europejskiej (TFUE) (2009), https:// eur-lex.europa.eu/legal-content/PL/TXT/HTML/?uri=CELEX:12 012E/TXT\&from $=\mathrm{PL}$

Traktat z Maastrich (Traktat o Unii Europejskiej - TUE) (1992), https://eur-lex.europa.eu/legal-content/PL/TXT/HTML/?uri=LEGISSUM:xyo026\&from=PL

Trevena P. (2008), Teorie i doktryny dotyczace integracji imigrantów. Doświadczenia tradycyjnych i nowych kręgów kulturowych, w: Problemy integracji imigrantów. Koncepcje, badania, polityki, (red.) Grzymała-Kazłowska A., Łodziński S., Wydawnictwo Uniwersytetu Warszawskiego, Warszawa

Weber M. (2002), Gospodarka i społeczeństwo. Zarys socjologii rozumiejacej, Wydawnictwo Naukowe PWN, Warszawa

Wu S., Schimmele Ch.M., Hou F. (2012), Self-perceived Integration of Immigrants and Their Children, "Canadian Journal of Sociology" Vol. 37, No. 4 